\title{
Improving learning infrastructure and environment for sustainable quality assurance practice in secondary schools in Ondo State, South-West, Nigeria
}

\section{Ayeni, Adeolu Joshua}

Ondo State Quality Education Assurance Agency, Akure, Nigeria (ayeniadeolu@yahoo.com)

Adelabu, Modupe A.

Obafemi Awolowo University, Ile-Ife, Nigeria (dupeadelabu@yahoo.com)

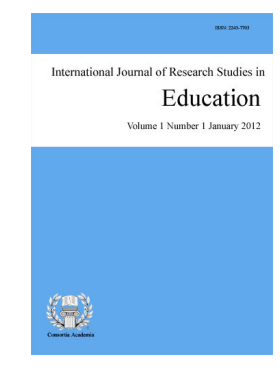

ISSN: $2243-7703$

OPEN ACCESS

\section{Abstract}

The current study examines the state of learning environment and infrastructure, together with their effects on teaching and learning activities and the extent to which they are being maintained. The study uses a descriptive survey design paradigm. Respondents consist of 60 principals and 540 teachers that were randomly selected using the multi-stage sampling technique from a pool of 599 public secondary schools in the Ondo State, South-West, Nigeria. Data were collected using the Learning Environment Management Questionnaire (LEMQ), the Teachers' Instructional Task Performance Rating Scale (TITPRS), and the Interview Guide for Principals (IGP). The study reveals that teachers' perception of the quality of learning infrastructure and environment ranges from 41 to $60.5 \%$, while the schools with inadequate quality range from 19 to $59 \%$. This implies that the quality assurance practice is at the average level in secondary schools. Result also reveals that there is a significant relationship between the teachers' instructional tasks and the students' academic performance $(\mathrm{r}=0.645$ at $p<0.05)$. The study concluded that the school and other stakeholders in education should effectively collaborate and contribute significantly towards the development of learning infrastructure and environment, so as to create a more conducive working environment for a sustainable high-quality education assurance practices in secondary schools.

Keywords: secondary school; quality assurance; learning infrastructure; learning environment; instructional performance; school principals; school plant maintenance; academic performance 


\section{Improving learning infrastructure and environment for sustainable quality assurance practice in secondary schools in Ondo State, South-West, Nigeria}

\section{Introduction}

Quality assurance is the systematic management, monitoring and evaluation procedure adopted to ensure that the learning environment and the curriculum program of an educational institution meet the specified standards to achieve the set goals and produce outputs that will satisfy the expectations of the institution's customers (society). Quality assurance oriented schools are characterized by core values and elements which were identified by UNICEF (2000) as: quality learners, learning environments, curriculum content, teaching and learning processes, and learning outcomes.

The societal expectation of quality outputs from the training institutions makes the students the primary focus of attention in any instructional program, and the better the school, the better it can meet the goals that include equipping the students with desirable skills, knowledge and attitudes that enable them to work and live in the society of knowledge. The teachers are expected to make teaching the learners' centered and create enabling environment for the students to interact with learning materials in order to concretize their knowledge and skills so that they can become self confident and self-reliant, and contribute meaningfully to the socio-economic development of the society.

There is actually a general belief that the condition of school's learning environment including infrastructure has an important impact on teachers' effectiveness and students' academic performance. The facilities that are needed to facilitate effective teaching and learning in an educational institution include the classrooms, offices, libraries, laboratories, conveniences and other buildings as well as furniture items and sporting equipment. The quality of infrastructure and learning environment has strong influence on the academic standard which is an index of quality assurance in the school. For instance, Earthman (2002), reporting on California, revealed that comfortable classroom temperature and smaller classes enhance teachers' effectiveness and provide opportunities for students to receive more individual attention, ask more questions, participate more fully in discussions, reduce discipline problems and perform better than students in schools with substandard buildings by several percentage points.

It is also not uncommon that facilities in most Nigerian public schools are dilapidated and inadequate to provide quality education service delivery (Sanusi 1998). For instance, Afolabi (2002), while reporting on Ondo state, mentioned that the classrooms in most of the schools were inadequate in terms of decency, space, ventilation and insulation from heat; the incinerators and urinal were not conveniently placed, and the school plant was poorly maintained; these combined deficiencies constituted a major gap in the quality of learning environment, thus the attendant result of non attainment of the set standards and goals in secondary schools.

\subsection{Learning Infrastructure and Quality Expectations}

The school learning infrastructure refers to the site, building, furniture and equipment that contribute to a positive learning environment and quality education for all students. The quality of learning facilities available within an educational institution has positive relationship with the quality of teaching and learning activities which in turn leads to the attainment of goals set. The quality of the school buildings and furniture will determine how long such will last while comfortable classrooms and adequate provision of instructional resources facilitate teachers' instructional task performance and students' learning outcomes.

The total development of the learners in the cognitive, affective and psychomotor domains of learning can only take place in an environment that is conducive to teaching and learning. The provisions of adequate and 
appropriate school physical facilities are indispensable in the educational process, where the school is located therefore, determines to a large extent the academic standard of a school. The school should be located where it is accessible and far from disturbance of markets, highways, airports and industries and free from filth and pollution. The environment of the school should stimulate, motivate and reinforce students' attendance in school. Comfortable classroom temperature and low noise level have positive influence on teachers' effectiveness and students' academic performance.

Ogundare (1999) and Olagboye (2004), viewed utilization of school infrastructure and learning environment as the extent of usage of school buildings, laboratories, library, assembly-ground, flower garden, school garden, volleyball field, chairs, desks, chalkboard, and so on. However, too much pressure on their use could result in over utilization, a situation that could lead to rapid deterioration and breakdown. For instance, when a classroom built to accommodate 40 students is constantly being used for 60 students then the returns from these facilities may not be maximized in terms of teaching and learning. Comfortable learning facilities will not only boost the morale of teachers and students but will also ensure the realization of the set educational objectives in secondary schools.

\subsection{Enhancement of Learning Environment for Quality Assurance}

Learning is a connection between response and stimuli. A good environment reinforces the efforts of the teacher by providing a good stimulus for effective teaching and learning to take place. Such a stimulus is not only provided by ensuring good physical plant planning but also through proper maintenance of such physical facilities. A good school environment where good working facilities exist is a catalyst for effective teaching and learning. In a school where there is enough space for the teachers to walk round in the classroom while delivering lesson will promote rapt attention of students and good academic performance.

A good school environment presents learning as a lifelong enterprise and enables students to discover appropriate value system that can be their compass for self-awareness and national consciousness. The study conducted by Hussain, Iqbal and Akhtar (2010) on public school in Islamabad in Pakistan revealed that teaching through technology based learning environment enhanced the achievement level of the students. To create good schools will take substantial financial resource allocation from the national budget, spent more strategically, with strong political commitment of government to ensure equity and universal access to education.

Effective management of learning infrastructure is the prime responsibility of the school principal and other stakeholders. The administrative responsibility for satisfactory physical environment is not limited to providing new facilities. The school heads should direct the available resources to the maintenance of learning facilities. Existing buildings must be maintained and made functional by providing proper lighting, ventilation and temperature condition for their effective and efficient utilization to ensure good working condition (Olagboye, 2004). Efficient management of school physical facilities is mandatory in order to make the school a pleasant, safe and comfortable centre that will increase students' attendance motivation and willingness to participate adequately in both curricula and co-curricula activities (Adeboyeje, 2000).

School heads are the custodians of their school plants. It is the responsibility of school heads to ensure that all components of the plant are in good working condition; that they are well protected; and that they are used for the purpose(s) for which they were acquired. It is the duty of the school heads to motivate staff members as well as the students to imbibe and internalize maintenance culture with respect to the school plant and even in personal affairs. The teachers are to assist the school heads in the maintenance of the school infrastructure and learning environment as this will create conducive teaching/learning environment and enhance their own work. Teachers are to see that every item in their classrooms (the classroom building, furniture, audio-visual and other teaching aids, etc) are in good condition and to promptly report any dilapidation or deterioration to the school head for necessary maintenance action.

In earlier studies carried out in Nigeria by researchers, such as, Durosaro (1998), on school plant planning 
and the administrative effectiveness of principals in secondary schools in Oyo revealed that schools that are well planned and maintained had higher student retention and even more effective than others. Buttressing this point, Durosaro (1998) reported that even if the educational curriculum is sound and well operated while the school facilities are in disrepair and badly managed, the result of the teaching/learning activities will be negative. This implied that there is a positive relationship between good school environment and effective teaching and learning activities. A similar study by Olutola (1989) on Kwara State revealed that schools adequately provided with the necessary facilities scored higher in their rate of utilization of instructional facilities and performance in West African School Certificate Examination subjects.

\subsection{Statement of Problem}

The relevant literature reviewed for this study revealed that many of the Nigeria's secondary schools face the combined challenges of deteriorating conditions, out-of-date design and capacity utilization pressures. These combined deficiencies impair the quality of teaching and learning and also create health and safety problems for staff and students. The effects of deteriorating condition and poor maintenance of school infrastructure are threats to school management, curriculum delivery and students' academic performance. The results of Senior School Certificate Examination conducted by the West African Examination Council and the National Examination Council were extremely poor in Nigeria between 2007 and 2010. The percentage of students who obtained credit level passes in five subjects and above including English Language and Mathematics was about 25\% in Nigeria and 35\% in Ondo state during the period under review (Bello-Osagie \& Olugbamila, 2010; Owadiae, 2010; Quality Education Assurance Agency, Akure, 2010). Also in 2011 May/June Senior School Certificate Examination conducted by the West African Examination Council, only 30.99\% of the 1,540,250 candidates obtained credit level passes and above in five subjects including English Language and Mathematics in the 36 States of the Federation, and the Federal Capital Territory (Owadiae, 2011).

The abysmal performance of students in examinations had been largely attributed to inadequate learning facilities. This situation has been a source of concern to the school administrators, government and other stakeholders. According to Fafunwa (2010), there is a big gap in quality, resulting from large number of students in crowded classrooms, using inadequate and obsolete equipment and with disillusioned teachers. These combined deficiencies perhaps constituted a major gap in the quality of learning infrastructure, thus, many challenges bear on teaching and learning that prevent the education system from getting the best out of its efforts to achieve the required level of attainment in teaching and learning activities in secondary schools. It is against this background that this study therefore looks into the identified gaps in school learning environment, with a view to determining their effect on quality assurance in secondary schools in Ondo state, which is the only state with an autonomous Quality Assurance Agency in South-West, Nigeria.

\subsection{Research Questions}

The following research questions were raised to guide the study:

1. What types of learning environment and infrastructure are available in secondary schools?

2. What are the effects of learning environment and infrastructure on teaching and learning in secondary schools?

3. How are learning environment and infrastructure being maintained in secondary schools?

\subsection{Objectives of the Study}

The study is set to achieve the following objectives:

1. Examine the state of learning environment and infrastructure in Ondo state secondary schools.

2. Determine the effects of learning environment and infrastructure on teaching and learning in secondary schools.

3. Investigate the extent to which learning environment and infrastructure are being maintained in 
secondary schools.

\subsection{Research Hypothesis}

The hypothesis generated to guide the study is: There is no significant relationship between teacher's instructional task performance and students' academic performance.

\section{Methodology}

The study employed the descriptive survey design. With this design, both quantitative and qualitative methods which involve systematic and objective collection and analysis of data were adopted to elicit responses from the participants in order to find solutions to the problems identified. The target population comprised principals and teachers in secondary schools in Ondo state. The sample consisted of 60 principals and 540 teachers randomly selected from 60 secondary schools using multi-stage sampling technique. The 60 secondary schools were selected from the existing 599 public secondary schools using stratified random sampling method from five (5) Local Government Areas (LGAs) that were randomly selected from the existing five educational zones in Ondo Sate. The instruments used for data collection were self-developed questionnaires named: Learning Facilities Management Questionnaire (LEMQ), Teachers' Instructional Task Performance Rating Scale (TITPRS) and Interview Guide for Principals (IGP).

The questionnaire contained two sections (A and B); section A of the IRMQ and TITPRS dealt with demographic and general information. The section B of the LEMQ instrument contained a total of 5 items developed by the researcher for the teachers to rate the adequacy of instructional materials, science laboratory and equipment, ICT facilities, technical and vocational equipment, library books and students' textbooks in secondary schools. The section B of the TITPRS elicited information on the following variables: planning and delivery of lessons, instructional material, learning resources, class management, record keeping, students' academic assessment, feedback and reviews of academic programs. Altogether the TITPRS instrument contained a total of 18 items constructed for the principals to rate teachers' instructional task performance and students' academic performance. The research instrument utilized a 5-point Likert scale questionnaire of Highly Agree, Agree, Fairly Agree, Disagree and Highly Disagree. The scale values allocated were 5, 4, 3, 2 and 1 respectively. In addition, the study made use of interview guide to collect information from principals on variables such as the nature of infrastructure and learning environment, recreational facilities, utilization and maintenance of infrastructure, and challenges of instructional practices. The interview was limited to three educational zones randomly selected from the five educational zones in the state. From each zone, one secondary school was randomly selected.

The instruments were validated using both content and construct validity. Each of the instruments was scrutinized by experts in Educational Administration, Test and Measurement, and Educational Technology in the Faculty of Education, Obafemi Awolowo University, Ile-Ife. Their suggestions were adhered to stricly and thus leading to the modification of relevant items. Ultimately, the instruments were adjudged to be suitable in measuring the constructs. Copies of the questionnaire were administered on the principals and teachers in their respective schools. Interview guide was used to collect qualitative data from principals. One research assistant was employed and trained to help the researcher in the administration of questionnaire. Interview guide was used to collect qualitative data from principals. One research assistant was employed and trained to help the researcher in the administration of questionnaire. Data collected was analyzed using percentages, mean scores and Pearson Product Moment Correlation analysis at 0.05 level of significance; using Statistical Package for Social Sciences (SPSS) version 16.0.

\section{Results}

The results presented in table 1 show the percentages and mean scores of teachers on quality of learning infrastructure and learning environment in secondary schools. The cumulative mean score was 1.56 . The highest 
Ayeni, A. J. \& Adelabu, M. A.

mean score of 1.81 was recorded on item 4. This implied that infrastructure and learning environment were adequately utilized in most of the secondary schools. Also, the results revealed adequacy of classrooms condition [60.5\%], staff rooms [49\%], recreational facilities [41\%], maintenance of infrastructure [50.1\%]. The study further indicated that the quality of learning infrastructure and environment were inadequate in classrooms condition [39.5\%], staffroom accommodation [51\%], recreational facilities [59\%], while learning infrastructure were under-utilized in $19 \%$ and poorly maintained in $49.5 \%$ of the secondary schools. This indicated that many schools were still striving to achieve quality assurance standard.

\section{Table 1}

Learning Infrastructure and Environment in Secondary Schools $(n=537)$

\begin{tabular}{|c|c|c|c|c|c|c|}
\hline \multirow[t]{3}{*}{ Item } & \multirow[t]{3}{*}{ Key Variables } & \multicolumn{4}{|c|}{ Frequency of Responses } & \multirow[t]{3}{*}{ Mean score } \\
\hline & & \multicolumn{2}{|c|}{ Adequate (2) } & \multicolumn{2}{|c|}{ Not adequate (1) } & \\
\hline & & Freq. & $\%$ & Freq. & $\%$ & \\
\hline 1 & Classroom facilities & 325 & 60.5 & 212 & 39.5 & 1.60 \\
\hline 2 & Staffroom facilities & 262 & 49 & 274 & 51 & 1.50 \\
\hline 3 & Recreational facilities & 220 & 41 & 317 & 59 & 1.41 \\
\hline 4 & Utilization of infrastructure & 435 & 81 & 102 & 19 & 1.81 \\
\hline \multirow[t]{2}{*}{5} & Maintenance of infrastructure & 271 & 50.1 & 266 & 49.5 & 1.50 \\
\hline & Cumulative mean & & & & & 1.56 \\
\hline
\end{tabular}

The result presented in table 2 showed that the $r$-value of 0.645 at $p<0.05$ is significant. The null hypothesis (Ho) of no significant relationship is rejected while the alternative hypothesis (Ha) is accepted. This shows that there is relationship between teachers' instructional task performance and students' academic performance. However, the mean score of 3.33 recorded on students' academic performance indicated that learning achievement is still low when compared with the mean score of 42.17 recorded on teachers' instructional task performance. This also implied that many secondary schools are still striving to achieve the desired quality in students' academic performance.

\section{Table 2}

Relationships between Teachers' Instructional Task Performance and Students' Academic Performance

\begin{tabular}{llllll}
\hline \multicolumn{1}{c}{ Item } & $n$ & $M$ & $S D$ & $r$ & $p$ \\
\hline Teachers' Instructional Task Performance & 60 & 42.17 & 5.87 & 0.645 & $<0.05$ \\
Students' Academic Performance & 534 & 3.33 & 0.76 & & \\
\hline
\end{tabular}

\section{Discussions}

\subsection{What types of learning environment and infrastructure are available in secondary schools?}

The result presented in table 1 showed that, teachers' perception of the adequacy of learning infrastructure and environment ranged from 41 to $60.5 \%$; this will no doubt enhance the quality of teaching and learning. The schools with inadequate learning infrastructure ranged from 19 to $59 \%$. There is no doubt that the inadequacies would have adverse effects on the quality of teaching and learning and might frustrate the attainment of quality assurance in secondary schools. The in-depth interviews conducted with the principals revealed that infrastructural facilities were inadequate, most of the buildings were old and without windows and the doors have no shutters while the class size was congested and ranged from 60-70 students per class. Many of the secondary schools lack well equipped laboratories and libraries. The school libraries were choky and lacked 
Improving learning infrastructure and environment for sustainable quality assurance

adequate relevant textbooks. There were multipurpose science laboratory as against the autonomous science subject laboratory.

\subsection{What are the effects of learning environment and infrastructure on teaching and learning in secondary}

schools?

The interviews with principals equally revealed that deficiencies in learning infrastucture and environment constituted impediments to effective classroom management, curriculum delivery and the full realization of secondary education objectives in Nigeria. According to Fafunwa (2010), there is a big gap in quality, resulting from large number of students in crowded classrooms, using inadequate and obsolete equipment and with disillusioned teachers. This was further supported by Okebukola (1996) as he identified lack of adequate infrastructure and large classes, as part of the major challenges to effective teaching and learning. Ipaye (2002) while stressing on teachers' apathy to teaching, identified some of the causes as poor condition in the rural area and lack of adequate infrastructure. In the same vein, Ayeni and Akinola (2008) recorded that most secondary schools lack well equipped staffrooms and more conducive classrooms to achieve quality assurance.

\subsection{Relationship between teachers' instructional task performance and students' academic performance}

The result presented in table 2 showed that there was relationship between teachers' instructional task performance and students' academic performance. However, the mean score of 3.33 recorded on students' academic performance indicated that learning achievement is still low when compared with the mean score of 42.17 recorded on teachers' instructional task performance. This situation could be attributed to some critical challenges facing the secondary school system in terms of congested classrooms condition, inadequate staffroom accommodation, recreational facilities and poor maintenance of learning infrastructure.

\subsection{How are learning environment and infrastructure being maintained in secondary schools?}

In the interviews with principals, one of them said that "the school relied mostly on the Parent-Teachers' Association for maintenance of infrastructure because of the limited grant-in-aids that was given by the state government. Consequently, there is lack of proper maintenance of the facilities in secondary schools". The other principals also affirmed this assertion as they attributed their inability to maintain school infrastructure to inadequate grant-in-aids from the state government. It is therefore evident from the results of the study that many of the secondary schools are not child-friendly and still striving to achieve quality assurance standard in learning infrastructure and students' academic performance.

\section{Conclusions}

The study looks into the identified gaps in school learning environment, with a view to determining their effect on quality assurance in secondary schools in Ondo state, which is the only state with an autonomous Quality Assurance Agency in South-West, Nigeria. Results of the study have concluded that there is a greater task ahead of school administrators, teachers and other stakeholders in meeting the challenges of unattractive and poor condition of school buildings, crowded classrooms, non-availability of recreational facilities and aesthetic surroundings which have perhaps contributed to poor quality teaching-learning process and the non-attainment of quality education by students in secondary schools.

\subsection{Recommendations}

Based on the findings and conclusion of the study, there is the need for effective collaboration between the school and other stakeholders to proactively and significantly contribute towards the development of solid learning infrastructure, so as to create conducive working environment for a sustainable high-quality education assurance practices in secondary schools. The financial resources needed to ensure adequate provision of 
Ayeni, A. J. \& Adelabu, M. A.

infrastructural facilities and grant- in-aids for proper maintenance of the facilities should be provided through increase in government's budgetary allocation, school internally generated revenue and community support, so as to create good and sustainable working climate for effective teaching and learning processes in secondary schools.

\section{References:}

Adeboyeje, R. A. (2000). A practical approach to effective utilisation and maintenance of physical facilities in Secondary schools. In J. O. Fadipe \& E. E. Oluchukwu (Eds.), A publication of The National Institute for Educational Planning and Administration (pp. 88-103). Ondo, Nigeria.

Afolabi, F. O. (2002). The school building and its environment. Implication on the achievement of functional Universal Basic Education programme in Ondo State. In T. Ajayi, J. O. Fadipe, P. K. Ojedele, \& E. E. Oluchukwu (Eds.), Planning and Administration of Universal Basic Education in Nigeria (pp. 101-110). Ondo: National Institute for Educational Administration and Planning (NIEPA).

Ayeni, A. J., \& Akinola, O. B. (2008). Influence of principals' leadership styles and motivation of teachers on quality assurance in secondary school: A case study of Ondo State. Ife Journal of Theory and Research in Education, 2(1\&2), 162-170.

Bello-Osagie, K., \& Olugbamila, A. (2009, December 31). Events that shape education. The Nation, p. B2.

Durosaro, D. O. (1998). School plant management in Nigeria: Trends, issues and problems in Management of Nigerian Education - Project monitoring and school plant maintenance. A publication of the National Institute for Planning and Administration, 2, 53-63.

Earthman, G. I. (2002). School facility conditions and student academic achievement. Los Angeles: University of California's Institute for Democracy, Education and Access. (http://www.ucla-idea.org)

Fafunwa, A. B. (2010, October 13). Fafunwa's last interview: Remember me as somebody who promoted use of mother tongue in schools. The Punch, $\mathrm{p} 3$.

Hussaain, M. A., Iqbal, M. Z., \& Akhtar, M. S. (2010). Technology based learning environment and student achievement in English as a foreign language in Pakistan. Journal of World Academy of Science, Engineering, and Technology, 61, 129-133.

Ipaye, B. (2002). Teachers' apathy to teaching. Journal of All Nigeria Conference of Principals of Secondary Schools, 2002, 185-198.

Ogundare, S. F. (1999). Community utilization of school facilities: An aspect of school community relationship in Nigeria. Journal of the National Institute for Educational Planning and Administration, 29(1), $115-121$.

Olagboye, A. A. (2004). Introduction to educational administration planning and supervision. Ikeja: Joja Educational Research and Publishers Ltd.

Olutola, A. D. (1989). Educational facilities and students' performance in West African school certificate examination. International Journal Educational Management, 1(1), 17-24.

Okebukola, P. (2002). Meeting the challenges of secondary school administration in Nigeria. Journal of All Nigeria Conference of Principals of Secondary Schools, 2002, 159-171.

Owadiae, I. (2010, August 31). West African Senior School Certificate Examination result. The Punch, p. 39.

Owadiae, I. (2011, August, 11). West African Senior School Certificate Examination result. The Nation, p. 4.

Quality Education Agency. (2010). Analysis of results of WAEC/NECO Senior Secondary School Certificate Examinations. Ondo state, Nigeria.

Sanusi, B. Y. (1998). Teachers job performance stress as a correlate to job satisfaction in selected Secondary schools in Ife Central Local Government zone of Osun State. Unpublished masteral thesis, Obafemi Awolowo University, Ile-Ife, Nigeria.

UNICEF (2000). Curriculum report card. Working paper series, Education Section Program Division. New York. 